\title{
Using climate finance to advance climate justice: the politics and practice of channelling resources to the local level
}

\author{
Sarah Colenbrander, David Dodman and Diana Mitlin
}

\section{Abstract}

Adaptation finance is primarily allocated to multilateral entities and national governments, rather than local organisations. This means that some of the same social, political and economic processes that create and sustain inequalities within a country will be the same processes that determine how adaptation finance is used. Using an urban lens, we consider the obstacles currently faced by local governments and local civil society groups in accessing adaptation finance, and show that these are a function of systemic power imbalances between levels of government, and between government and vulnerable communities. We argue that even relatively small amounts of adaptation finance could have a catalytic effect on the capacities and impacts of local organisations, contributing to greater levels of both distributive and procedural justice. We analyse different financial intermediaries and planning systems that could be used to make disbursements from multilateral climate funds fairer and more effective. This could potentially create political opportunities both to respond to direct climate threats and to address underlying drivers of vulnerability, such as marginalisation and exclusion. In this way, channelling adaptation finance to the local level could deliver more just processes and outcomes.

\section{Policy insights}

1. More multilateral climate funds should establish direct access modalities, and introduce "fit-for-purpose" accreditation procedures and approval processes. Those that have already established such enabling frameworks should prioritise providing readiness support to local organisations, and incentivise state and citizen collaboration in adaptation projects.

2. National governments should consider clearly enshrining the rights and responsibilities of local authorities in National Adaptation Plans, and help them to collect the information, build the capacities and acquire the resources needed to plan and implement adaptation measures. National governments should further encourage local authorities to adopt participatory planning, budgeting, monitoring and evaluation procedures to encourage citizen participation.

3. Local civil society groups should identify or establish collective entities that can seek accreditation with multilateral funds and then disburse money to their members. Collaboration between groups can facilitate up-scaling through replication (particularly where peer-to-peer learning is embedded in the network) and reduce the transaction costs associated with myriad small projects. 
Low-income and other marginalised groups will suffer disproportionately from climate change impacts. This is because climate risk is not just a product of increased environmental shocks and stresses, but also of existing social, political and cultural factors (IPCC, 2014). Countries in the global South are more vulnerable than those in the North because they have limited resources, inadequate infrastructure and weak systems of governance. Lowincome and other marginalised groups are more vulnerable to climate change than other segments of the population because these factors are amplified. Although these groups will bear the brunt of its impact, they have contributed the least to climate change (Roberts, 2009; Schlosberg, 2012). This is widely recognised to be unjust.

We recognise the importance of justice both in terms of philosophical debates about how society should be governed and organised (Rawls 1999), and through the priorities of lowincome and disadvantaged groups themselves (Bebbington et al 2010). Fraser (2008) argues that there are three dimensions to a relational approach to justice: recognition, representation and redistribution. In international contexts, climate justice is widely understood to encompass both 'distributive' and 'procedural' mechanisms (Bulkeley et al., 2013; Comim, 2008; Grasso, 2009; Paavola and Adger, 2006). Distributive justice describes the allocation of costs and benefits. Procedural justice describes the power relations around planning and decision-making processes; realising procedural justice recognises and enables low-income groups to be involved in decision-making and, potentially, subsequent implementation projects.

To date, adaptation finance ${ }^{1}$ has been viewed in part as a means to increase justice through redistributing resources from countries that have generated the greenhouse gas emissions that drive global warming, to countries that experience or are expected to experience the most severe effects. Where procedural justice has been considered, this has largely been at the national and international level: developing countries push to have equal if not majority representation on the boards of multilateral climate funds (Ciplet et al., 2013), while donor countries are expected to recognise country ownership by providing adaptation finance to implement National Adaptation Plans (NAPs). Yet most adaptation finance is managed by multilateral entities and national governments, and only a small proportion of resources are channelled to the local level, let alone to locally-designed and locally-led resilience initiatives (Fenton et al., 2015). This means that resource allocation continues to be determined by elites within development agencies and government ministries. In other words, some of the social, political and economic processes that create and sustain inequalities within a country will typically be the same processes that allocate climate

\footnotetext{
${ }^{1}$ Definitions of climate finance vary: the term can be narrowly used to refer to new and additional public finance from global North to South, or more widely to refer to any expenditure on climate change mitigation and adaptation (Buchner et al., 2014). For the purposes of this paper, we focus on resources committed to support resilience and adaptation activities in the global South as part of the UNFCCC process, and disbursed through multilateral climate funds including the Green Climate Fund, Adaptation Fund, Least Developed Countries Fund, Climate Investment Funds, Strategic Climate Fund, Global Facility for Disaster Reduction and Recovery and Pilot Program for Climate Resilience, among others.
} 
finance. Adaptation finance may therefore advance climate justice between countries while doing little to enhance climate justice within countries.

One way of delivering greater climate justice is to ensure that climate finance contributes to recognition and representation as well as redistribution. This is also likely to result in fairer distributional outcomes. The existing literature recognises that a multi-scalar approach, supporting participation at a range of different levels, could enhance procedural justice (Barrett, 2012; Okereke et al., 2009; Paavola and Adger, 2006). In this paper, we extend this principle to adaptation finance, exploring how local organisations - both local authorities and local civil society groups - could play a more significant role in its governance and use. In light of anticipated increases in flows of adaptation finance, this is an important extension of debates around climate justice.

Channelling adaptation finance to the local level may increase distributional justice by increasing the share of resources reaching the most vulnerable. More importantly, devolving planning and resources to the local level can facilitate access to and influence over decision-making for a wider range of stakeholders. Increasing local control over adaptation finance offers an opportunity to strengthen civil society and local government, and thereby redress power imbalances that fuel inequality and exclusion. We recognise that there are risks involved; channelling finance to the local level could support patronage networks and clientelism, over-burden local actors with responsibilities beyond their existing capabilities, formalise their processes leading to new exclusions, and/or make such organisations donor-driven rather strengthening local accountabilities. However, and as we explain below, while continuing efforts are required, recent practices have introduced methods to reduce these risks. Moreover, it is evident that a more sustainable and resilient urban future will be within, and not outside of, local democracy. This is only possible with sustained efforts to equip and resource local authorities to respond effectively to challenges such as climate change, and to establish processes and systems that enable urban residents to hold these public bodies to account and to strengthen co-productive relations to adapt to climate change.

While this argument is relevant to a wide range of settings, we focus on urban areas in lowand middle-income countries. Due to the concentration of people and economic activity, urban areas are highly vulnerable to the impacts of climate change (Rosenzweig et al. 2011, Revi et al. 2014). For example, future water stress is likely to be concentrated in fastgrowing cities (Vörösmarty et al., 2000) while heatwaves will have the most severe consequences in cities due to urban heat island effects (McMichael et al., 2006; Patz et al., 2005). The importance of considering domestic politics in adaptation planning is also particularly evident in urban contexts (Bulkeley et al., 2014), where inequality and exclusion physically manifest in the juxtaposition of soaring skyscrapers and sprawling, pejoratively named "slums". Adopting an urban lens highlights the political implications of different uses and allocations of climate finance, particularly the risk that it will be deployed in ways that reinforce rather than redress inequalities. It also draws on new practices of self-organization and citizen state collaboration. We therefore illustrate our argument for devolving climate finance with the examples of local governments in urban areas and organised groups of the low-income citizens. 
In this paper, we outline the ways that local governments and local civil society groups can increase the adaptive capacity of urban residents. We then explain our methodology. The subsequent section identifies the barriers to disbursing adaptation finance to local organisations, illustrating how power relations favouring national and formal agencies create various economic, technical and institutional obstacles for local organisations. This analysis informs our assessment of the financial intermediaries and planning systems that could be deployed to allow local organisations to access adaptation finance. Finally, we illustrate how municipal authorities and organised groups of urban residents have used small amounts of resources to shift political dynamics. This demonstrates the scope for adaptation finance to have a transformational impact on procedural as well as distributive climate justice.

\section{The Role of Local Organisations in Building Climate Resilience}

Local governments are often responsible for risk-reducing infrastructure and services, such as drains, all-weather roads, emergency services, healthcare and solid waste collection (Satterthwaite and Mitlin, 2014). Local governments are additionally responsible for designing and enforcing regulatory frameworks that contribute to public health and safety, such as building regulations, traffic control, zoning and pollution control (Dodman and Satterthwaite, 2008). These powers mean that municipal authorities also have unique opportunities to enhance climate resilience. High population density means that local governments can provide risk-reducing trunk infrastructure, such as water pipes, sewers and roads, at lower per capita cost than in rural areas (Turok and McGranahan, 2013). Upgrading well-located informal settlements can facilitate densification, enabling other urban residents to relocate away from hazard-prone areas while retaining proximity to employment and services.

Both with and without government investment, local civil society groups, particularly community-based organisations, can contribute to adaptation both instrumentally (by acting directly to address particular hazards) and transformatively (by engaging with social and political issues that drive vulnerability in cities and shifting both public opinion and state action towards adaptation and mitigation). Firstly, community-based organisations can implement development projects which generate immediate livelihood benefits while building financial management and implementing capacities at the local level (Sharma et al. 2014). There is a rich heritage of cost-effective small infrastructure projects that meet the needs of residents of low-income and informal settlements, a growing number of which show how local civil society groups can reduce climate-related risk: building decentralised drainage systems in Gorkahpur, India (Mani and Wajih, 2014); using rainwater harvesting to service community sanitation blocks in Kampala and Mbarara, Uganda (Dobson et al., 2015); and organised relocation driven by community priorities in lloilo, the Philippines (Dodman et al., 2010). In many cases, low-income urban residents have been able to collectively negotiate with local government and then co-produce risk-reducing services and infrastructure at a much larger scale (Mitlin, 2008; Watson, 2014). These community-led approaches can help blend priorities of different groups and over different timescales, enabling low-income and marginalised urban residents to address adverse shifts in climate simultaneously with addressing other development needs. 
Secondly, local civil society can act in a more transformative way by mediating between individual and collective responses to climate impacts. Norms around participation in decision-making determine whose voices are heard and whose interests are represented in political processes (Tyler and Moench, 2012). Involvement is recognition and representation in itself; but it also builds a platform for further justice though strengthening the individual and collective capabilities of marginalised groups. Community-based organisations that facilitate collective action are likely to increase resilience, for example because members are more likely to pool resources and share information about risks and opportunities (Agrawal et al., 2008). Grassroots organisations may provide a conduit for information between local government and residents, strengthening accountabilities between citizens and the state as networks of community organizations ensure that policies, programmes and decisions are made public. Simply improving access to knowledge can build adaptive capacity (Williams et al., 2015), but it is worth highlighting that this information flows both ways: local governments can disseminate information through community-based organisations, but organised groups of urban residents have a much better understanding of stressors and priorities on the ground, particularly in informal settlements, than government representatives (Ayers, 2011). Drawing on this local knowledge to guide adaptation planning and investments can generate additional poverty reduction and livelihood improvements (Archer et al., 2014; Fenton et al., 2014). These relationships with government bodies can also facilitate better representation and participation in decision-making processes, ensuring that public interventions engage with issues of power, voice and equity, rather than reinforcing adverse structures and processes (Friend and Moench, 2013; Chelleri et al., 2015). Strengthening community networks and federations and building institutional links between these aggregations of community associations and local government builds civil society-driven accountabilities that can prevent abuse. Innovations in new forms of organization and relations within communities and between communities and the state are on-going but progress is already evident (ACHR, 2017).

Local organisations will only contribute substantively to resilience if they are accountable to those who most sensitive to climate impacts. This means that both municipal governments and civil society groups must be responsive to local needs and concerns, with mechanisms for meaningful citizen participation and oversight. Otherwise devolution of powers and resources is unlikely to address current practices of elite capture and will also fail to address the drivers of vulnerability.

\section{Methodological approach}

This discussion draws on our individual and collective experiences with climate change adaptation in urban areas. We have participated in the strategies, plans and activities of numerous agencies working at multiple scales from the very local (i.e. informal settlement neighbourhood) to the international. Through our long-term exposure to the perspectives and work of a range of local civil society organizations, including community groups, national and international federations of shack dwellers, informal workers associations and NGOs, we have understood both the potential contribution of these groups and the obstacles that they face to effective action. Particularly important has been our exposure to 
the urban social movements of SDI, their associated professional support agencies and their local funds, and their partnerships with local authorities. ${ }^{2}$ We have been directly involved in capitalising, evaluating and designing financing mechanisms to channel international development assistance to grassroots organisations of the urban poor, and have assisted to document and share this work.

Our engagement with local government has also been important, both in the provision of basic services and informal settlement upgrading, and in their work to respond to climate change and its effects. This has included engagements with the work of individual municipal authorities in Africa and Asia (including training municipal officials on adaptation planning), and participation in meetings and activities that have framed collective views and sometimes formal statements such as the Durban Adaptation Charter. ${ }^{3}$ Our work with local civil society organisations and local governments has taken place over the last 20 years and in cities in more than 15 countries in sub-Saharan Africa and Asia.

In terms of a methodological tradition, this research approach is very similar to the form of political ethnography described by Auyero (2006); repeated encounters have enabled us to engage with the realities of politics as observed by multiple individuals who have offered insights into "...the texture of political life, and the plight of political actors", as well as political processes and outcomes (page 258). In particular, we have been actively involved in diverse initiatives to channel international public finance (including from multilateral climate funds) to local urban organisations. In this paper, we bring this detailed knowledge and experience of local civil society groups and local government to international debates around the governance and distribution of climate finance.

Barriers to Channelling Adaptation Finance to Local Organisations

\footnotetext{
${ }^{2} \mathrm{SDI}$ are an international network of federations of women-led savings schemes based in informal settlements and other low-income neighbourhoods, and their support NGOs. The federations are active in over 500 cities around the world.

${ }^{3}$ The Durban Adaptation Charter was initiated at UNFCCC COP17 in Durban in 2011, and has more than 1000 sub-national government signatories worldwide (www.durbanadaptationcharter.org).
} 
-Sub-national governments and civil society from the global South are excluded from national and international decision-making processes.

-Informal organisations are often excluded from formal decision-making processes (Oberlack and Eisenack, 2014).

-Accountability is structured upwards rather than downwards, so that donor interests outweigh recipient needs (Barrett, 2012; Barrett, 2014).

-Multi-level governance arrangements constrain scope for action by local governments (Gouldson et al., 2015; Kithiia, 2011), with local organisations viewed as competitors for limited funds rather than delivery partners (van Kerkhoff et al., 2011).

\section{Legal obstacles}

- Climate finance can often only be distributed to central governments or with a sovereign guarantee (Paulais and Pigey, 2010; van Kerkhoff et al., 2011).

- Local organisations often lack the legal powers (municipal authorities) or rights (community organisations) to implement key adaptation measures (Oberlack and Eisenack, 2014).

- Governments at all levels may refuse to work with or even recognise residents of informal settlements if they see them as illegal (Satterthwaite et al., 2007).

\section{Economic requirements}

-Donors often display a preference for large-scale projects, as small-scale projects are thought to have higher transaction costs (van Kerkhoff et al., 2011).

- The lending criteria of multilateral funds indicate a preference for investments in 'hard' infrastructure such as sea walls, which tend to be delivered by high-level government bodies, rather than 'soft' infrastructure such as capacity building and raising awareness, which tend to be delivered (and required) by local organisations (Fankhauser and Burton, 2011).

\section{Capacity deficits}

- Local organisations often lack the technical capacity to navigate the institutional architecture of climate finance or to implement adaptation projects (e.g. for urban planning, project design and delivery).

- Local civil society organisations and local government may lack the financial capacity to manage large sums of money or to leverage co-financing; these agencies also have limited scope for revenue generation to repay loans.

Figure 1. Barriers to directing international climate finance through and to local-level organisations.

There are significant obstacles to distributing climate finance to the local level (Figure 1). These barriers are not equal, and do not occur at the same time. Notably, some climate funds are only permitted to provide funding to national governments, while others can only offer loans with a sovereign guarantee. The legal definitions of which organisations are eligible to receive climate finance might be the first, insurmountable barrier for local organisations, such that the others are ultimately irrelevant.

The direct access modalities of the Adaptation Fund and Green Climate Fund, and the small grants programme of the Global Environmental Facility, offer alternatives to this centralised approach. These modalities devolve project implementation to entities that have satisfied an accreditation process and secured a 'no objection' letter from the national designated 
authority or focal point. While direct access modalities offer much greater scope for local organisations to plan and manage projects financed by the multilateral funds, preliminary quantitative analysis demonstrates that this potential is not being realised. Figure 2 presents the value of monies committed by the Adaptation Fund and the Green Climate Fund as of March 2017. Only 36.2 per cent of resources committed by the Adaptation Fund and only 6.2 per cent of those committed by the Green Climate Fund are to National Implementing Entities: the remainder has been or will be disbursed through International Implementing Entities such as the multilateral development banks and United Nations agencies. Figure 2 further shows that only a tiny number of the successful National Implementing Entities have been local civil society organisations, while no sub-national governments have directly received finance from this channel. A separate study suggests that under 10 per cent of finance from specialised climate funds was approved for locally-focused climate projects between 2003 and 2016 (Soanes et al., 2017).

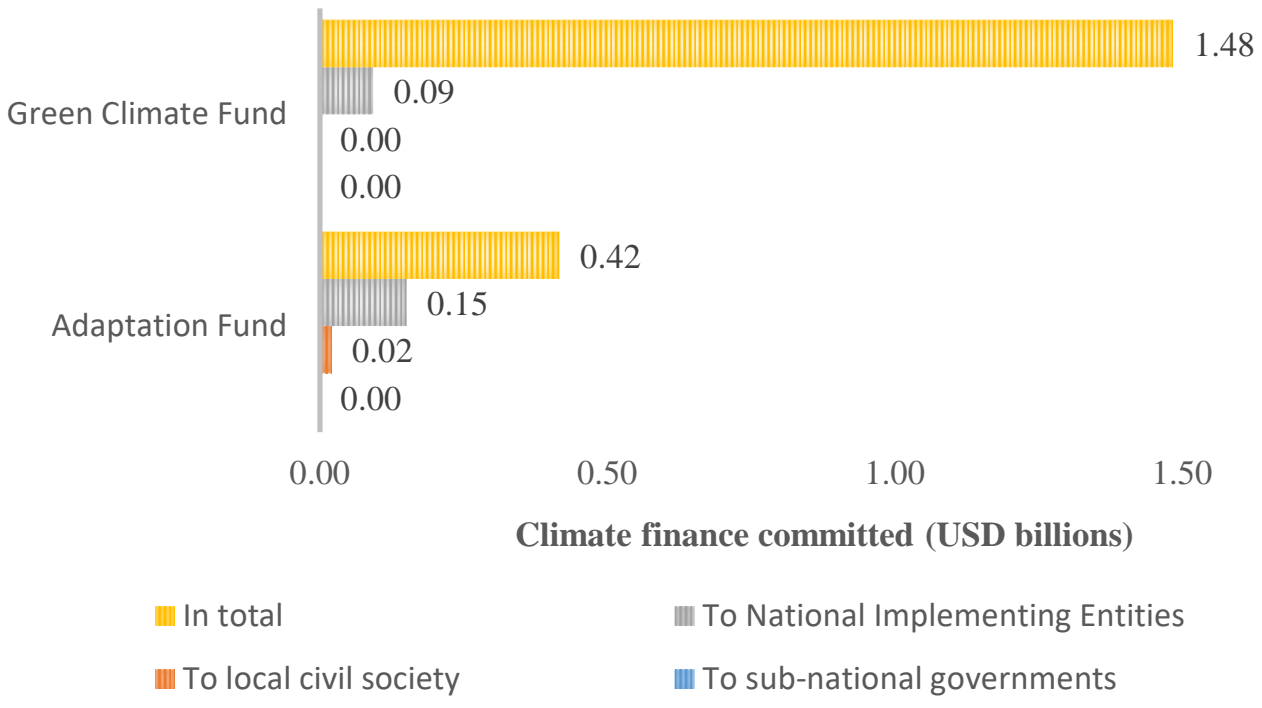

Figure 2. The value of climate finance committed by the Adaptation Fund and Green Climate Fund to different implementing entities. ${ }^{4}$

Central governments may also be unwilling or unable to support projects led by local governments or local civil society groups. Few low- and lower middle-income countries have the enabling multi-level governance arrangements in place that could equip local authorities to act effectively on climate change (Gouldson et al., 2015; Kithiia, 2011). City governments not only face the challenge of poor coordination among agencies; sometimes, national governments can actually view sub-national governments as competitors, either for limited funds (van Kerkhoff et al., 2011) or for political power (Resnick, 2011).

\footnotetext{
${ }^{4}$ Data drawn from the project databases of the Green Climate Fund (http://www.greenclimate.fund/projects/browse-projects) and the Adaptation Fund (https://www.adaptationfund.org/projects-programmes/) in March 2017.
} 
Local civil society groups are likely to face even more pronounced barriers than sub-national governments. Many are composed of people and communities that are systematically marginalised, either informally or by law (for example, women, ethnic minorities and migrants). Formal agencies may refuse to recognise those that they deem illegitimate, such as the residents of "illegal" settlements (Satterthwaite et al., 2007). Because people who live in informal settlements are rarely recognised by, or represented in, government, they have limited avenues to demand greater distributive justice. In many cities of the global South, governments have actively thwarted organised groups of urban residents seeking to improve service delivery (Tacoli et al., 2008). These systemic power imbalances contribute to vulnerability, yet can also make it difficult for the most vulnerable to benefit from adaptation finance: a stark example of climate injustice.

\section{Integrating Local Organisations into the Landscape of Climate Finance}

To contribute effectively to both distributive and procedural justice, the global adaptation finance architecture needs to channel funds more effectively to local civil society organisations and local government. Although local organisations can advocate for change, they cannot dismantle many of these barriers themselves. They will typically need to work through financial intermediaries and experiment with new financial planning systems to access adaptation finance. Donor agencies and national governments may also need to take action to channel resources to local organisations.

\section{Financial Intermediaries}

Financial intermediaries are the agencies that enable climate finance to flow from its source to users (Kaur et al., 2014). Only accredited entities may submit proposals to multilateral climate funds, so local organisations must either achieve accreditation or work with an accredited entity. The accreditation process is intended to ensure that climate funds are disbursing resources to entities with satisfactory fiduciary, environmental and social policies, and entails complicated application, evaluation, monitoring and reporting procedures.

Some local organisations may be well-positioned to seek accreditation, particularly if they have expertise in project financial structuring, due diligence and operational and management activities. Compliance with climate funds' criteria might be relatively straightforward for, for example, the small number of city governments in the global South that have achieved satisfactory credit ratings in domestic capital markets, such as Cape Town, Mexico City and Mumbai. Some local civil society organisations may also have established sufficiently rigorous fiduciary, environmental and social standards, particularly if they have previously sought international development assistance.

Yet navigating the stringent requirements of the multilateral funds poses a significant organisational and financial challenge to most potential local users of adaptation finance (Afful-Koomson, 2015; Druce et al., 2013). Moreover, the emphasis on strong financial management favours vertical authority and centralised decision-making, overlooking consequences for organizations that prioritise horizontal accountabilities. There is evidence, 
for example, that the allocation of adaptation finance has sometimes been determined by the political and economic preferences of government more than by the nature and level of vulnerability (Barrett, 2015). Formalisation also favours the participation of those who are literate and formally educated, and many community networks seek to ensure the equal participation of those whose homes and livelihoods are embedded in the informal sector. Hence compliance may exacerbate recognised problems in local organizations.

There is therefore a need to identify or establish accredited entities that are both willing to work with local organisations and able to secure approval (and possibly a sovereign guarantee) from the national designated authority. One promising strategy is aggregation, whereby local organisations collectively establish an agency or network that can seek accreditation and then disburse money to its members. This could ensure that local actors, particularly those at the level in which adaptation is operationalised, are involved in formulating and implementing projects. It could also facilitate horizontal replication, whereby successful initiatives are reproduced in multiple locations through knowledge transfer and peer-to-peer learning (Fenton et al., 2014). From the perspective of multilateral climate funds, agglomeration can also reduce the transaction costs associated with accrediting multiple entities and managing myriad smaller projects. And aggregations can strengthen social accountabilities minimising both the risk that local elites will capture benefits and that processes will be poorly designed and inappropriate for the most disadvantaged groups.

Municipal governments could apply through national agglomerations such as the municipal development funds established in Brazil, Colombia and Morocco. They could also collaborate through city networks, which have an impressive record in fostering, supporting and implementing climate action (Castán Broto, 2017). The C40 Cities Finance Facility, for instance, has been capitalised by the German Federal Ministry for Economic Cooperation and Development (BMZ) and the United States Agency for International Development (USAID) to support the preparation of bankable climate projects, develop the financial capacities of city administrations and initiate partnerships between cities and prospective financiers (including climate funds) (C40 Cities, 2017).

Local civil society groups can similarly collaborate to establish subsidiaries that comply with international accounting procedures without disadvantaging the very members that the network has been established to serve. Notable examples include the Urban Poor Fund International (managed by and for SDI), which has channelled $\$ 20$ million to its members, and the Asian Coalition for Community Action, which has channelled \$10 million to its members (Mitlin, 2013). These funds are governed by representatives of national federations of slum/shack dwellers and were initially capitalised by members' savings. As the Urban Poor Fund International achieved compliance with donor requirements, these savings have been blended with grants from the Bill and Melinda Gates Foundation and the Swedish International Development Cooperation Agency.

However, the onus of urban climate justice should not be entirely on local organisations: multilateral climate funds also have responsibilities to further justice through improving their distributions and procedures. Accordingly, climate funds can support local financial intermediaries by establishing direct access modalities, as the Adaptation Fund has done; 
introducing "fit-for-purpose" accreditation procedures and simplified approval processes for small-scale projects, as the Green Climate Fund is doing; and by providing readiness support to local organisations and/or networks of such organisations.

\section{Financial Planning Systems}

Financial planning systems play an important role in governing flows of climate finance. These can be formal or informal, and within or among organisations (Kaur et al., 2014). Effective local use of adaptation funds will require institutional and organisational arrangements to be based on the principles of subsidiarity, where matters are handled by the lowest or least centralised competent authority, and partnership, where all actors recognise that different constellations of individuals and organisations may be best positioned to deliver different goods and services.

With respect to subsidiarity, specific responsibilities should be defined in legislation along with adequate powers and resources to plan, regulate and manage provision of infrastructure and basic services. National governments can support local organisations by collecting information, investing in in human capital, disseminating best practice, establishing clear regulatory frameworks and providing adequate resources (Ayers, 2009; Fünfgeld, 2010). Some central governments have demonstrated their willingness to channel climate finance to the local level: Nepal has committed to invest at least 80 per cent of climate-sensitive expenditure at the local level, which gives local organisations the mandate and resources to coordinate adaptation planning (Sharma, 2014), while Kenya is establishing devolved and participatory agencies to secure and disburse climate finance, building on the success of the Isiolo County Adaptation Fund (Hesse and Pattison, 2013). However, it is important to recognise that in many cases such legislation is of little meaning as it has no influence over government practices. Financial planning systems need to be sensitive to the underlying incentives and shadow systems that drive or constrain good practice (Leck and Roberts, 2015).

The principle of partnership is particularly important where local governments are unable to deliver basic services and infrastructures: citizens and communities seeking to fill the gap should be accepted and supported. Yet discussions about adaptation planning and budgeting systems have largely neglected the importance of legal and budgetary instruments that allow input from citizens and communities (Schaeffer and Yilmaz, 2008). Without measures being introduced that enable participation, the devolution of climate finance to local government may exacerbate bureaucratic control and patronage, rather than increase local discretion and downwards accountability (Mansuri and Rao, 2013). National governments can advance procedural justice by encouraging local governments to adopt participatory budgeting systems, a common practice in Brazilian cities (Cabannes, 2004), or participatory monitoring and evaluation procedures, as Uganda has done (Lwasa, 2015). There remains a risk that climate and other development interventions could serve the interests of the elite, but a commitment to recognition and representation could "shift the terms of debate [and] make space for alternatives" (Bulkeley et al., 2014: pp 33). 
While there is some acknowledgement of the potential role for local communities in receiving adaptation finance, there are concerns that existing climate funds are not taking on this challenge (for example, see Funder et al., 2015). The gap between declaration and practice may reduce the legitimacy of international agencies and result in increasing frustration within local communities in need. Citizen engagement with government should therefore be incentivised by the adaptation finance architecture in order to enhance the adaptive capacity of the most vulnerable. The planning and budgeting systems for adaptation finance need to include bottom-up processes to link local organisations with accredited entities. This must be more than access to information, permission to co-produce services or the right to make complaints: local civil society groups should be involved in decision-making around the allocation and use of adaptation finance. The cross-cutting nature of adaptation means that these reforms offer a platform to enhance procedural justice in all aspects of urban governance. By raising the profile and amplifying the voice of vulnerable residents, these changes to the climate finance architecture positions them to engage with wider fiscal policy, social policy, and the efficiency, accountability and transparency of public expenditure (Schaeffer and Yilmaz, 2008).

\section{A Virtuous Cycle of Locally-Led Development?}

This assessment of the adaptation finance landscape suggests that there are financial intermediaries and planning systems available that could be used to deliver resources from multilateral climate funds to the local level. Yet the scope to channel adaptation finance to the local level is curtailed by processes that favour the national over the local and the formal over the informal, reflecting long-standing power relations and potentially preventing the citizen empowerment needed to address the underlying drivers of climate vulnerability.

In most contexts, two substantial changes are necessary. First, national and multilateral agencies need to recognise the critical role that both local civil society organisations and local governments can and should play in adaptation. Second, this paradigm shift must drive national and multilateral agencies to change norms of representation and redistribution, so that the agency and priorities of groups vulnerable to climate change are at the heart of decision-making. Tackling both issues could catalyse a virtuous cycle, whereby local civil society organisations working with local government can demonstrate their contribution to urban resilience, thereby securing further support that in turn enhances their ability to act. The opportunities for transformative change are apparent when we consider two specific examples: improved financial management by city governments and changed urban planning practices driven by community saving groups.

Many local municipal authorities depend on transfers from state and central governments, while others rely on narrow revenue bases: revenues of local governments in India, for example, were less than 1 per cent of national GDP in 2007-2008 (Rao and Bird, 2010) and expenditure by local governments in sub-Saharan Africa was less than 8 per cent of central government expenditure (UCLG, 2010). It is therefore unsurprising that local governments struggle to provide basic services and infrastructure, let alone redress historical infrastructure deficits. Adaptation finance cannot meet this shortfall, partially because of the sheer scale of infrastructure investment needs and partially because climate funds will 
not allocate resources to organisations that are unable to demonstrate robust fiduciary practices.

In order to satisfy the fiduciary principles and standards of climate funds, local governments will need to improve and demonstrate their financial credentials. ${ }^{5}$ They can do this by implementing discrete, cost-effective projects, and/or by through better collection of local revenue. Readiness funding could support the processes of developing bankable project proposals and improving municipal practices, while the prospect of securing adaptation finance may provide the necessary incentive for city leaders. While adaptation finance may be the short-term goal, these steps would also help local governments to increase local revenue generation, improve the regulatory environment for private investment and gain access to debt finance (bank loans and domestic capital markets). This has been the experience of Kampala: incentivised by the possibility of issuing a municipal bond, the city government succeeded in increasing local revenue streams by US\$10 million in 2010/11 to US\$30 million in 2014/15 (KCCA, 2016). In most cities, improved tax collection and access to bank loans could support climate-relevant and risk-reducing investment on a much larger scale than climate finance. Using adaptation finance to support and incentivise the development of key capabilities - planning and budgeting, project implementation, financial management - could thereby have a multiplier effect on municipal authorities' ability to lead and deliver climate-resilient development.

Faced with political exclusion and inadequate access to financial and other services, community savings groups have emerged as a way for urban residents to better use resources. Savings provides a platform to organise and mobilise urban residents, who subsequently negotiate and advocate to secure land tenure and basic services. As the groups have demonstrated their accountability and effectiveness, donors and governments have begun to supplement community savings with development assistance and public finance as outlined above (also: Bolnick, 2017). Funds such as the Urban Poor Fund International continue to be locally managed, so any investments incorporate local knowledge and are primarily accountable to communities rather than donors.

These community savings groups have underpinned a mass movement that has catalysed broader political change by incentivising decision-makers to listen to low-income groups (Mitlin, 2013). There are varied manifestations of community funds that use local savings to change urban planning practices and leverage additional public resources. For example, the City of Harare has co-financed an upgrading fund with SDI to enable organized communities to take loans for infrastructure improvements (Shand, 2015), while the SDI affiliate in India has been able to access state and market subsidies to provide new dwellings and upgrade informal settlements (SPARC, 2015). Archer (2012) summarises the experience of the Asian Coalition of Housing Rights with catalysing city development funds in Thailand, while ACHR (2017) expands on the outcomes that five member organizations have achieved. In each

\footnotetext{
${ }^{5}$ For example, the Green Climate Fund requires all entities to have statements that provide information on their financial position (assets, liabilities and fund balances), financial performance (income and expenses/revenue and expenditure); cash flows; and accounting policies administered transparently in accordance with pertinent regulations and laws (GCF, 2011). Many municipal authorities do not have the necessary track record in the preparation of business plans, financial projections and budgets, or the evaluation of performance and expenditure against these.
} 
case, a relatively small fund created from savings has enabled a radical shift in urban governance, with greater recognition and representation of low-income groups as a precondition for substantial redistribution. Disbursing adaptation finance to communitybased organisations of this kind could amplify their achievements, equipping them with the platforms and financial capacities to build more equal partnerships with government agencies and to hold those agencies accountable to urban residents (Newell, 2008).

We recognise that adaptation finance cannot, on its own, overcome all sources of social injustice and disadvantage. However, channelling international resources to the local level could help to address the underlying causes of vulnerability, such as exclusion and marginalisation, and contribute to greater climate justice. The experiences of city creditworthiness initiatives and community saving groups illustrate the way that small amounts of finance can have a catalytic effect on the capacities and impacts of local organisations.

\section{Using Adaptation Finance to Enhance Procedural Justice}

Too often, the idea of 'common but differentiated responsibilities' is applied only among rather than within nations. Even in a single city, communities will have differing obligations to mitigate and different adaptation needs (Dodman, 2009; Steele et al., 2015). Similarly, adaptation is too often understood as a technical or technological matter, inspiring debate around the design of infrastructure rather than the design of organisational practices and relations (Pelling, 2011). These tensions are particularly manifest in contexts of urban inequality, where prevailing modes of development either relegate disadvantaged residents to risky areas (such as floodplains) or create additional hazards in low-income areas (such as air pollution) (Shi et al., 2016). Climate change will only exacerbate these injustices.

Meaningful and long-term adaptation will require - but should also contribute to - reform of existing social and political structures. Currently, the climate finance architecture risks entrenching differential access to state investments and continuing political exclusion (Barrett et al., 2013). Neither the conclusion that climate change responses should be just, nor the observation that many adaptation processes are exclusionary are new. Our contribution is to argue that there are emerging capabilities particularly within some local civil society agencies that enable these outcomes to be reversed, and to demonstrate how this might work with respect to adaptation finance.

Three interventions appear both important and over-due, and in this respect there is the potential for multilateral climate funds to offer global leadership.

1. Appreciation of the significance of community-led organizations in addressing the needs of the most vulnerable citizens, and the establishment of more inclusive processes and structures at the international, national and sub-national scales to ensure that vulnerable groups can access and influence decision-making. These reforms must go beyond narrow interpretations that focus on national representation, for example, on the boards of climate funds. 
2. Commitment to distribute adaptation finance to organizations of those vulnerable to climate change. This should happen through three routes; direct to international networks of community-led organisations where possible; to joint projects of local civil society and local government; and to national agencies working in partnership with community-based organisations. These changes should be designed to encourage greater recognition, representation and redistribution within cities and countries.

3. An active programme of research and learning to understand what works in terms of improving the use of adaptation monies so that the benefits identified above can be secured.

These recommendations highlight that recognition is a precondition for furthering other facets of justice, whether procedural or distributive (Bulkeley et al., 2014). They also underscore the importance of attributing rights and responsibilities across different scales. Local organisations can and arguably should undertake to improve their fiduciary procedures and social and environmental standards. In a suitably enabling environment, this can have a transformative effect on their capacities to respond to climate change. However, multilateral climate funds must also adopt various innovations and reforms if they are to contribute to enhanced justice below the national scale. The aim of both top-down and bottom-up efforts should be to facilitate meaningful public engagement in urban climate adaptation planning and implementation, through some combination of participatory decision-making processes and robust partnerships between key public and civil society actors (Chu et al., 2016).

Resourcing and empowering local civil society groups and local government can instrumentally reduce vulnerability by improving their ability to (co-)produce services and infrastructure that reduce exposure to risk. Perhaps even more importantly, this approach offers new incentives for national governments to support and collaborate with local governments, and strengthens the power of community-based organisations trying to hold governments accountable to citizens. In this way, disbursing adaptation finance to local civil society organisations carves out the political space for them to use adaptation as a means to pursue justice across multiple dimensions of urban development.

While challenging power relations in this way is likely to be politically contested in both international and domestic arenas, we argue that adaptation finance should be delivered in ways that enhance procedural justice as well as distributive justice. This means that it must be deployed in ways that reconfigure political relationships to promote more inclusive processes as well as more equitable outcomes. Only then can adaptation finance begin to address the injustices that underlie climate vulnerability.

\section{References}

Afful-Koomson T. 2015. The Green Climate Fund in Africa: what should be different? Climate and Development. 7(4) 367-379 DOI: 10.1080/17565529.2014.951015

Agrawal A, McSweeney C, Perrin N. 2008. Local Institutions and Climate Change Adaptation. The Social Dimensions of Climate Change No. 113. World Bank. Washington, D.C. 
Archer D. 2012. Finance as the key to unlocking community potential: savings, funds and the ACCA programme. Environment and Urbanization. 24(2) 423-440 DOI: $10.1177 / 0956247812449235$

Archer D, Almansi F, DiGregorio M, Roberts D, Sharma D, Syam D. 2014. Moving towards inclusive urban adaptation: approaches to integrating community-based adaptation to climate change at city and national scale. Climate and Development [Communitybased adaptation: Mainstreaming into national and local planning]. 6(4) 345-356 DOI: $10.1080 / 17565529.2014 .918868$

ACHR (Asian Coalition for Housing Rights). 2017. Community Finance in Five Asian Countries. ACHR. Bangkok

Ayers J. 2009. International funding to support urban adaptation to climate change. Environment and Urbanization. 21(1) 225-240 DOI:10.1177/0956247809103021

Ayers J. 2011. Resolving the adaptation paradox: Exploring the potential for deliberative adaptation policy-making in Bangladesh. Global Environmental Politics. 11(1) 62-88 DOI:10.1162/GLEP_a_00043

Auyero J. 2006. Introductory Note to Politics under the Microscope: Special Issue on Political Ethnography I. Qualitative Sociology. 29(Fall) 257-59.

Barrett S. 2012. The necessity of a multiscalar analysis of climate justice. Progress in Human Geography. 37(2) 215-233 doi: 10.1177/0309132512448270

Barrett S. 2013. Local level climate justice? Adaptation finance and vulnerability reduction. Global Environmental Change. 23(6) 1819-1829

Barrett S. 2014. Subnational climate justice? Adaptation finance distribution and climate vulnerability. World Development. 58 130-142 DOI:10.1016/j.worlddev.2014.01.014

Barrett S. 2015. Subnational Adaptation Finance Allocation: Comparing Decentralized and Devolved Political Institutions in Kenya. Global Environmental Politics. 15(3) 118-139 DOI:10.1162/GLEP_a_00314

Bebbington A, Mitlin D, Mogaladi J, Scurrah M, Bielich C. 2010. Decentring Poverty, Reworking Government: Social Movements and States in the Government of Poverty. Journal of Development Studies. 46(7) 1304-26.

Bolnick J. 2017. Where will the money come from? SDI and Local Level Finance. International Institute for Environment and Development. London, UK. Available from: http://pubs.iied.org/10177IIED/

Buchner B, Stadelmann M, Wilkinson J, Mazza F, Rosenberg A, Abramskiehn D. 2014. The Global Landscape of Climate Finance. Climate Policy Initiative. Available from: http://climatepolicyinitiative.org/wp-content/uploads/2014/11/The-GlobalLandscape-of-Climate-Finance-2014.pdf [retrieved 05/10/2015]

Bulkeley H, Carmin JA, Castán Broto V, Edwards GAS, Fuller S. 2013. Climate justice and global cities: Mapping the emerging discourses. Global Environmental Change. 23(5) 914-925 DOI: 10.1016/j.gloenvcha.2013.05.010

Bulkeley H, Edwards GAS, Fuller S. 2014. Contesting climate justice in the city: Examining politics and practice in urban climate change experiments. Global Environmental Change. 25 31-40 doi:10.1016/j.gloenvcha.2014.01.009

C40 Cities. 2017. C40 Cities Finance Facility. Available from: http://www.c40.org/programmes/c40-cities-finance-facility

Cabannes Y. 2004. Participatory budgeting: a significant contribution to participatory democracy. Environment and Urbanization. 16(1) 27-46 DOI: $10.1177 / 095624780401600104$ 
Castán Broto V. 2017. Urban governance and the politics of climate change. World Development. 93 1-15 DOI: 10.1016/j.worlddev.2016.12.031

Chelleri L, Waters JJ, Olazabal M, Minucci G. 2015. Resilience trade-offs: addressing multiple scales and temporal aspects of urban resilience. Environment and Urbanization, 118. DOI:10.1177/0956247814550780

Chu E, Anguelovski I, Carmin J. 2016. Inclusive approaches to urban climate adaptation planning and implementation in the Global South. Climate Policy. 16(3) 372-392

Ciplet D, Roberts JT, Khan M. 2013. The politics of international climate adaptation funding: justice and divisions in the greenhouse. Global Environmental Politics. 13(1) 49-68 DOI:10.1162/GLEP_a_00153

Comim F. 2008. Climate injustice and development: A capability perspective. Development. 51(3) 344-349 doi:10.1057/dev.2008.36

Dobson S, Nyamweru H, Dodman D. 2015. Local and participatory approaches to building resilience in informal settlements in Uganda. Environment and Urbanization. 27(2) 115 DOI: $10.1177 / 0956247815598520$

Dodman D, Satterthwaite D. 2008. Institutional Capacity, Climate Change Adaptation and the Urban Poor. IDS Bulletin. 39(4) 67-74 DOI: 10.1111/j.1759-5436.2008.tb00478.x

Dodman, D. 2009. Blaming cities for climate change? An analysis of urban greenhouse gas emissions inventories. Environment and Urbanization. 21(1) 185-201 DOI: 10.1177/0956247809103016

Dodman D, Mitlin D, Co JR. 2010. Victims to victors, disasters to opportunities: Communitydriven responses to climate change in the Philippines. International Development Planning Review, 32(1) 1-26

Druce L, Grüning C, Menzel D. 2013. Key messages on direct access to international climate funds from participants of the NCFISP. Frankfurt School-UNEP Collaborating Centre for Climate and Sustainable Energy Finance. Available from: http://fs-unepcentre.org/sites/default/files/project/1/policy_brief_direct_access.pdf [retrieved 15/10/2015]

Fankhauser S, Burton I. 2011. Spending adaptation money wisely. Climate Policy. 11(3) 1037-1049 DOI: 10.1080/14693062.2011.582389

Fenton A, Gallagher D, Wright H, Huq S, Nyandiga C. 2014. Up-scaling finance for community-based adaptation. Climate and Development [Community-based adaptation: Mainstreaming into national and local planning]. 6(4) 388-397 DOI: 10.1080/17565529.2014.953902

Fenton, A., Reid, H., Wright, W., Huq, S. 2015. Ten principles to help assess funding for local climate adaptation. International Institute for Environment and Development. London, UK. Available from: http://pubs.iied.org/17323IIED/

Fraser N. 2008. Scales of Justice: Reimagining Political Space in a Globalizing World. Polity. Cambridge, UK.

Friend R, Moench M. 2013. What is the purpose of urban climate resilience? Implications for addressing poverty and vulnerability. Urban Climate. 6 98-113. DOI: 10.1016/j.uclim.2013.09.002

Funder M, Christoplos I, Friis-Hansen E, Lindegaard L, Pain A. 2015. Making the Green Climate Fund work for the poor. DIIS Policy Brief March 2015. Danish Institute for International Studies. Copenhagen, Denmark. Available from: https://www.files.ethz.ch/isn/189588/pb_green_climate_fund_web.pdf 
Fünfgeld H. 2010. Institutional challenges to climate risk management in cities. Current Opinion in Environmental Sustainability. 2(3) 156-160 DOI:10.1016/j.cosust.2010.07.001

GCF. 2011. Annex II: Initial fiduciary principles and standards of the Fund. Green Climate Fund. Songdo, Korea.Available from: https://www.greenclimate.fund/documents/20182/319135/1.6__Fiduciary_Standards.pdf/083cfe10-46f4-4a73-b603-8d7bfd2a35bd

Gouldson A, Colenbrander S, Sudmant A, Papargyropoulou E, Kerr N, McAnulla F, Hall S. 2015. Cities and Climate Change Mitigation: Economic opportunities and governance challenges in Asia. Cities. 54. 11-19. DOI: 10.1016/j.cities.2015.10.010

Grasso M. 2009. Justice in Funding Adaptation under the International Climate Change Regime. Springer. Heidelberg, Germany. DOI: 10.1007/978-90-481-3439-7

Hardoy, Jorge E, Diana Mitlin and David Satterthwaite (2001), Environmental Problems in an Urbanizing World, Earthscan, London

Hesse C, Pattison J. 2013. Ensuring devolution supports adaptation and climate resilient growth in Kenya. International Institute for Environment and Development. London, UK Available from: http://pubs.iied.org/17161IIED.html [retrieved 30/09/2015]

IPCC. 2014. "Summary for policymakers." In: Climate Change 2014: Impacts, Adaptation, and Vulnerability. Part A: Global and Sectoral Aspects. Contribution of Working Group II to the Fifth Assessment Report of the Intergovernmental Panel on Climate Change [Field CB, Barros VR, Dokken DJ, Mach KJ, Mastrandrea MD, Bilir TE, Chatterjee M, Ebi KL, Estrada YO, Genova RC, Girma B, Kissel ES, Levy AN, MacCracken S, Mastrandrea PR, White LL (eds.)]. Cambridge University Press, Cambridge, United Kingdom and New York, USA, pp. 1-32.

Kaur N, Rwirahira J, Fikreyesus D, Rai N, Fisher S. 2014. Financing a transition to climateresilient green economies. International Institute for Environment and Development. London, UK. Available from: http://pubs.iied.org/pdfs/17228IIED.pdf [retrieved 30/09/2015]

KCCA. 2016. Improving Municipal Financial position. Kampala Capital City Authority. London, UK. Available from: https://www.theigc.org/wp-content/uploads/2016/02/MusokePresentation-to-LSE-in-LONDON-FINAL.pdf

Kithiia J. 2011. Climate change risk responses in East African cities: need, barriers and opportunities. Current Opinion in Environmental Sustainability. 3(3) 176-180 DOI:10.1016/j.cosust.2010.12.002

Leck H, Roberts D. 2015. What lies beneath: understanding the invisible aspects of municipal climate change governance. Current Opinion in Environmental Sustainability. 13 6167 DOI: 10.1016/j.cosust.2015.02.004

Lwasa S. 2015. Urban governance and poverty reduction in Uganda: lessons from foreign aid regime of Local Government Development Program. Current Urban Studies. 3 25-34 DOI: 10.4236/cus.2015.31004

Mani N, Wajih S. 2014. A participatory approach to micro-resilience planning by community institutions: The case of Mahewa ward in Gorakhpur City. Asian Cities Climate Resilience Working Paper 7. International Institute for Environment and Development, London.

Mansuri G, Rao V. 2013. Localizing Development: Does Participation Work? World Bank. Washington D.C. DOI: 10.1596/978-0-8213-8256-1 
McMichael AJ, Woodruff RE, Hales S. 2006. Climate change and human health: present and future risks. The Lancet. 367(9513) 859-869 doi:10.1016/S0140-6736(06)68079-3

Mitlin D. 2008. With and beyond the state - coproduction as a route to political influence, power and transformation for grassroots organizations. Environment and Urbanization. 20 339-360.

Mitlin D. 2013. Locally managed funds: a route to pro-poor urban development. International Institute for Environment and Development. London, UK. Available from: http://pubs.iied.org/pdfs/17154IIED.pdf [retrieved 06/10/2015]

Newell P. 2008. Civil society, corporate accountability and the politics of climate change. Global Environmental Politics. 8(3) 122-153 DOI:10.1162/glep.2008.8.3.122

Oberlack C, Eisenack K. 2014. Alleviating barriers to urban climate change adaptation through international cooperation. Global Environmental Change. 24 349-362 DOI:10.1016/j.gloenvcha.2013.08.016

Okereke C, Bulkeley H, Schroeder H. 2009. Conceptualizing Climate Governance Beyond the International Regime. Global Environmental Politics. 9(1) 58-78 DOI:10.1162/glep.2009.9.1.58

Paavola J, Adger WN. 2006. Fair Adaptation to Climate Change. Ecological Economics. 56(4) 594-609 DOI:10.1016/j.ecolecon.2005.03.015

Patz JA, Campbell-Lendrum D, Holloway T, Foley JA. 2005. Impact of regional climate change on human health. Nature. 438 310-317 doi:10.1038/nature04188

Paulais T, Pigey J. 2010. "Adaptation and Mitigation: What Financing is Available for Local Government Investments in Developing Countries?" In: Hoornweg D, Freire M, Lee MJ, Bhada-Tata P, Yuen B (eds). Cities and Climate Change: Responding to an Urgent Agenda (Volume 2). World Bank. Washington, D.C. 583-601

Pelling M. 2011. Adaptation to Climate Change: From Resilience to Transformation. Routledge. Oxon.

Rao MG, Bird RM. 2010. Urban Governance and Finance in India. National Institute of Public Finance and Policy. Working Paper No. 2010-68. Available from: http://www.nipfp.org.in/media/medialibrary/2013/04/wp_2010_68.pdf [retrieved 06/10/2015]

Resnick D. 2011. In the shadow of the city: Africa's urban poor in opposition strongholds. The Journal of Modern African Studies. 49(1) 141-166

Revi A, Satterthwaite D, Aragón-Durand F, Corfee-Morlot J, Kiunsi R, Pelling M, Roberts D, Solecki W (2014). "Urban areas". In: Climate Change 2014: Impacts, Adaptation, and Vulnerability. Part A: Global and Sectoral Aspects. Contribution of Working Group II to the Fifth Assessment Report of the Intergovernmental Panel on Climate Change. Cambridge University Press, Cambridge, United Kingdom and New York, NY, USA, pp. 535-612.

Roberts JT. 2009. The international dimension of climate justice and the need for international adaptation funding. Environmental Justice. 24(4) 185-190 doi:10.1089/env.2009.0029.

Rosenzweig C, Solecki W, Hammer S, Mehrotra S (eds.) (2011). Climate Change and Cities: First Assessment Report of the Urban Climate Change Research Network. Cambridge: Cambridge University Press.

Satterthwaite D, Huq S, Pelling M, Reid H, Lankao Romero P. 2007. Adapting to climate change in urban areas: the possibilities and constraints in low-and middle-income 
nations. Human Settlements Discussion Paper Series, Climate Change and Cities 1, IIED, London.

Satterthwaite D, Mitlin D. 2014. Reducing Urban Poverty in the Global South. Routledge. Abingdon, UK.

Schaeffer M, Yilmaz S. 2008. Strengthening Local Government Budgeting and Accountability. World Bank Policy Research Working Paper 4767. Available from: http://papers.ssrn.com/sol3/papers.cfm?abstract_id=1297806 [retrieved 23/10/2015]

Schlosberg D. 2012. Climate justice and capabilities: A framework for adaptation policy. Ethics \& International Affairs [Safeguarding Fairness in Global Climate Governance]. 26(4) 445-461 DOI: http://dx.doi.org/10.1017/S0892679412000615

Shand W. 2015. Exploring Institutional Change: The Contribution of Co-Production to Shaping Institutions. International Institute for Environment and Development. London, UK.

Sharma V, Orindi V, Hesse C, Pattison J, Anderson S. 2014. Supporting local climate adaptation planning and implementation through local governance and decentralised finance provision. Development in Practice [Special Issue on climate change adaptation and development]. 24(4) 579-590 DOI: 10.1080/09614524.2014.907240

Sharma HP. 2014. Climate change financing in Nepal. International Institute for Environment and Development. Available from: http://pubs.iied.org/pdfs/17229IIED.pdf [retrived 22/10/2015]

Shi L, Chu E, Anguelovski I, Aylett A, Debats J, Goh K, Schenk T, Seto KC, Dodman D, Roberts D Roberts JT, VanDeveer SD. 2016. Roadmap towards justice in urban climate adaptation research. Nature Climate Change. 6(2) 131-137

Soanes M, Rai N, Steele P, Shakya C, MacGregor J. 2017. Delivering real change: Getting international climate finance to the local level. International Institute for Environment and Development. London, UK. Available from: http://pubs.iied.org/10178IIED/

SPARC. 2015. Annual Report 2014-5. Society for the Promotion of Area Resource Centres. Mumbai, India.

Steele W, Mata L, Fünfgeld H. 2015. Urban climate justice: creating sustainable pathways for humans and other species. Current Opinion in Environmental Sustainability. 14 121126

Tacoli C, McGranahan G, Satterthwaite D. 2008. "Urbanisation, Poverty and Inequity: Is Rural Urban Migration a Poverty Problem or Part of the solution?" In G Martine, G McGranahan, M Montgomery, R Fernandez-Castilia (Eds) The New Global Frontier: Urbanization, Poverty and Environment in the 21 ${ }^{\text {st }}$ Century. Earthscan. London. 37-54

Turok I, McGranahan G. 2013. Urbanization and economic growth: the arguments and evidence for Africa and Asia. Environment and Urbanization, 25(2) 465-482.

Tyler S, Moench M. 2012. A framework for urban climate resilience. Climate and Development. 4(4) 311-326, DOI:10.1080/17565529.2012.745389

UCLG. 2010. Local Government Finance: the challenges of the $21^{\text {st }}$ Century: Second Global Report on Decentralization and Local Democracy. Gold II. Cheltenham: Edward Elgar Publishing. 
van Kerkhoff L, Ahmad IH, Pittock J, Steffen W. 2011. Designing the Green Climate Fund: How to spend $\$ 100$ billion sensibly. Environment: Science and Policy for Sustainable Development. 53(3) 18-31 DOI: 10.1080/00139157.2011.570644

Vörösmarty CJ, Green P, Salisburgy J, Lammers RB. 2000. Global water resources: vulnerability from climate change and population growth. Science. 289(5477) 284288 DOI: $10.1126 /$ science.289.5477.284

Watson V. 2014. Co-production and collaboration in planning - The difference. Planning Theory \& Practice. 15(1) 62-76 DOI: 10.1080/14649357.2013.866266

Williams C, Fenton A, Huq S. 2015. Knowledge and adaptive capacity. Nature Climate Change. 5 82-83 
